\title{
Meta Analysis Study: Risk Factors Related To The Events Of Loss Of Chronic Energy (KEK) In Pregnant Women
}

\author{
Ida Sumiati ${ }^{1}$, Nia Kania ${ }^{2}$, Syamsul Arifin ${ }^{2}$, Meitria Syahadatina Noor ${ }^{2}$, Husaini ${ }^{2}$ \\ ${ }^{1}$ Student of the Master of Public Health Science Study Program \\ ${ }^{2}$ Lecturer in the Master of Public Health Science Study Program, Faculty of Medicine, Lambung Mangkurat University \\ DOI: 10.29322/IJSRP.11.01.2021.p10975 \\ http://dx.doi.org/10.29322/IJSRP.11.01.2021.p10975
}

\begin{abstract}
Chronic Energy Deficiency (KEK) in pregnant women is still a serious problem in Indonesia. According to Riskesdas data in 2018, the prevalence of KEK in pregnant women in Indonesia reaches $17.3 \%$. The purpose of this paper is to conduct a literature review to explain the factors associated with the incidence of KEK in pregnant women. There are 10 research articles related to factors related to the incidence of KEK in pregnant women obtained from the results of collection through Google Scholar, Garuda Portal, and Research Gate. The type of research used is Meta Analysis. Based on the results of the review of research articles, it was found that there were 6 research articles that discussed age and the incidence of KEK in pregnant women. There were 4 research articles that stated that there was a relationship while 2 research articles stated that there was no relationship, so it could be concluded that there was a relationship between age and the incidence of KEK in pregnant women. There are 5 research articles that discuss maternal education with the incidence of KEK in pregnant women. There were 2 research articles which stated that there was a relationship while 3 research articles stated that there was no relationship so it could be concluded that there was no relationship between education and the incidence of KEK in pregnant women. There are 5 research articles that discuss the relationship between maternal occupation and the incidence of KEK in pregnant women.
\end{abstract}

Index Terms- chronic energy deficiency, pregnant women

\section{INTRODUCTION}

$\mathrm{C}$ hronic Energy Deficiency (KEK) in pregnant women is still a serious problem in Indonesia. KEK is a condition when the mother experiences food shortages for a long time which can have health impacts on the mother and the fetus. The state of chronic energy deficiency is caused by lack of nutritional intake such as energy and protein, and then the nutrients needed by the body are not fulfilled (Prastuty, 2018).

Indonesia is one of the ASEAN country where nutritional problems in pregnant women are still widely encountered, nutrition problems that occur in pregnant women, including pregnant women who suffer from KEK (LILA $<23.5 \mathrm{~cm}$ ) are still high. According to Basic Health Research data (Riskesdas) in 2018 , the prevalence of KEK in pregnant women in Indonesia reaches 17.3\% (Riskesdas, 2018).

According to Call and Lenvison (1974) in Supariasa (2002) nutritional status is influenced by main factors, that are food consumption and health level, especially the presence of infectious diseases. The factors that cause KEK in pregnant women are very complex, including the lack of education and knowledge about the nutrition needed so that their babies have good nutrition so that they can be born normally. Family income and maternal occupation, age of pregnant women and pregnancy spacing. Measurement of LILA is a way that can be done to find out someone suffering from chronic energy deficiency. However, LILA measurements cannot be used to monitor changes in nutritional status in the short term (Supriasa, 2002).

Several studies have proven the relationship of the variables to be studied with the incidence of KEK in pregnant women. The variables studied were also supported by previous studies.However, due to differences in the results of these studies, this is not in line with the theory used. Based on the description above, a meta-analysis study is needed to analyze the risk factor trends associated with the incidence of KEK in pregnant women.

\section{RESEARCH METHOD}

The method used is to collect and analyze research articles related to risk factors associated with the incidence of CED in pregnant women. Meta-analysis studies were conducted on research aimed at explaining the risk factors associated with the incidence of CED in pregnant women. The results of the search for articles as a whole were obtained as many as 737 research articles which were then screened and obtained 185 relevant research articles. Then obtained 20 full text research articles and tested for feasibility in the end, obtained 10 research articles that correspond to the research topic related to risk factors associated with the incidence of KEK in pregnant women obtained from the results of collection through Google Scholar, Garuda Portal, and Research Gate. The data analysis used is the SPIDER method. All articles analyzed with a time span from 2015-2020 discuss the incidence of KEK in pregnant women in full text format. 


\section{RESULTS AND DISCUSSION}

The results of the journal data synthesis that have been reviewed will be discussed in terms of similarities between journals, inequality and giving views on the results of research. This discussion will be discussed below:

1) Similarity

The similarities discussed in this section explain that There is a relationship between the independent variable and the dependent variable, that are the age variable found similarities in research results, that are exist relationship between age and the incidence of KEK in pregnant women discussed in research articles Triatmaja (2017), Ernawati (2018), and Andriani (2019). Then in Andini's research (2020), Tejayanti (2019), and Nurdin (2018) also statedthere is a relationship between age and the incidence of KEK in pregnant women. In the variable level of mother's education there is also a relationship with the incidence of KEK in pregnant womenwhich is discussed in the research articles of Andini (2020) Ervinawati (2018), and Tejayanti (2019). As for the research, Nurdin (2018) also statedthere is a relationship between the mother's education level and the incidence of KEK in pregnant women. In the variable of mother's work, there is also a relationshipwith the incidence of KEK in pregnant women which is discussed in in research articles by Mahirawati (2014), Ernawati (2018), and Andini (2020).

2) Inequality

The inequalities discussed in this section make it clear that they are not There is a relationship between the independent variable and the dependent variable, that are the age variable It was found that the inequality of the research results showed that there was no relationship between age and the incidence of KEK in pregnant women discussed in the research of Najwa (2020), and Ervinawati (2018). At the education level variable, there are also articles that state there is no relationship discussed in the research articles of Triatmaja (2017), Mahirawati (2014), and Indriany (2014). As for the variable of maternal occupation, there is also research which states that there is no relationship discussed in the research article, Najwa (2020), and Indriany (2014).

3) Gives A View

The view of researchers towards journals that have been reviewed is that when viewed from the writing of research articles that have been reviewed as a whole it is quite good. As for the variables studied, the research articles that were reviewed were in accordance with the inclusion criteria determined by the researcher. In addition, most of the research results that have been found indicate that the variables of age, mother's education and maternal occupation are risk factors for the incidence of KEK in pregnant women and overall these variables are related to the incidence of KEK in pregnant women.

\section{DISCUSSION}

According to Call and Lenvison (1974) the nutritional status of a person or society is influenced by two main factors, that are food consumption and health level, especially the presence of infectious diseases. Both factors are direct causes. Meanwhile, the indirect causes are the addiction of nutrients in food, the presence or absence of feeding outside the family, people's purchasing power, food habits, health care, and the physical and social environment (Supapai, 2002).

Then in the theory of UNICEF (1998) the factors that cause chronic energy deficiency problems that occur in pregnant women are divided into two, that are direct and indirect causes. One of the direct causes of chronic energy deficiency pregnant women is insufficient nutritional consumption and infectious diseases, while the indirect causes are lack of knowledge, education, insufficient food supply, inadequate parenting, and inadequate environmental health and health services. inadequate (UNICEF, 1998). The results of a review of research articles based on variables are as follows:

\section{The relationship between age and the incidence of KEK in pregnant women}

Based on the results of the study, there were 8 research articles that discussed age. A total of 6 research articles (75\%) stated that there is a relationship between age and the incidence of KEK in pregnant women. Meanwhile, 2 research articles $(25 \%)$ stated that age did not correlate with the incidence of KEK in pregnant women.

Based on the results of a review of 8 research articles, there are 6 research articles which state that age is related to the incidence of KEK in pregnant women, where most of the research results state that respondents have an age above 35 years, which age is at risk of pregnancy. Meanwhile, 2 research articles stated that there was no relationship because the overall results of the study stated that the age of the respondents studied was not at risk for the incidence of KEK. Thus it can be concluded that the tendency of the results is more to the relationship between age and the incidence of KEK in pregnant women because if the pregnant age is more than 35 years, the pregnancy is very risky with the incidence of CED

\section{Relationship between mother's education with the incidence of KEK in pregnant women}

Based on the results of the study, there were 7 research articles that discussed maternal education. As many as 4 research articles $(57.1 \%)$ stated that there was a relationship between maternal education and the incidence of KEK in pregnant women. While 3 research articles $(42.9 \%)$ stated that there was no relationship between maternal education and the incidence of KEK in pregnant women.

Based on the results of a review of the 7 research articles, there are 4 research articles which state that maternal education is related to the incidence of KEK in pregnant women where the results of the study state that most respondents have low education. This is because education affects the diet of pregnant women, a higher level of education is expected to have better knowledge or information about nutrition so that they can meet their nutritional intake. Meanwhile, 3 research articles stated that there was no relationship between education and the incidence of KEK in pregnant women because the overall results of the study stated that the respondents' education was high. Thus it can be concluded that the trend of the results is more to no relationship between maternal education and the incidence of KEK in pregnant women because mothers who have higher education are expected to have high knowledge related to good eating patterns so that mothers can apply a good diet in daily life. -day. A good diet will

This publication is licensed under Creative Commons Attribution CC BY.

http://dx.doi.org/10.29322/IJSRP.11.01.2021.p109XX

WwW.ijsrp.org 
support the realization of a good nutritional status.

\section{Relationship between mother's job with the incidence of KEK in pregnant women}

Based on the results of the study, there were 5 research articles that discussed maternal work. As many as 3 research articles (60\%) stated that there was a relationship between maternal occupation and the incidence of KEK in pregnant women. Meanwhile, 2 research articles $(40 \%)$ stated that there was no relationship between maternal occupation and the incidence of KEK in pregnant women.

Based on the results of a review of the 5 research articles, there are 3 research articles which state that maternal occupation is related to the incidence of KEK in pregnant women where the results of the study state that most of the respondents work which one working mothers will feel more stressed, have irregular lifestyles and eating patterns so it is not impossible if mothers can be at risk of chronic energy deficiency.Meanwhile, 2 research articles stated that there was no relationship between maternal occupation and the incidence of KEK in pregnant women because the results of the overall study stated that most respondents did not work. Thus it can be concluded that the trend of results is more to the relationship between maternal occupation and the incidence of $\mathrm{KEK}$ in pregnant women because working mothers have a risk of experiencing KEK incidence in pregnant women.

\section{CONCLUSION}

From the meta-analysis study it can be concluded that the risk factors are associated with the incidence of CED in pregnant women. Based on the results of the review that has been carried out, it can be concluded that as follows:

1. In the variable age with the incidence of KEK in pregnant women, the result is that There are 6 research articles $(75 \%)$ stating that there is a relationship between age and the incidence of KEK in pregnant women. Meanwhile, 2 research articles $(25 \%)$ stated that there was no relationship between age and the incidence of KEK in pregnant women. The trend that can be concluded is that there is a relationship between age and the incidence of KEK in pregnant women.

2. In the variable of maternal education with the incidence of KEK in pregnant women, the results are There are 4 research articles $(57.1 \%)$ stating that there is a relationship between maternal education and the incidence of KEK in pregnant women. Meanwhile, 3 research articles (42.9\%) stated that there was no relationship between maternal education and the incidence of KEK in pregnant women. The trend that can be concluded is that there is a relationship between maternal education and the incidence of KEK in pregnant women.

3. In the variable of maternal occupation with the incidence of KEK in pregnant women, the result is that There are 5 research articles that discuss maternal work. As many as 3 research articles $(60 \%)$ stated that there was a relationship between maternal occupation and the incidence of KEK in pregnant women. Meanwhile, 2 research articles (40\%) stated that there was no relationship between maternal occupation and the incidence of KEK in pregnant women. The trend that can be concluded is that there is a relationship between maternal occupation and the incidence of KEK in pregnant women

\section{REFERENCES}

[1] Adriani dan Susilawati. 2019. Kejadian kekurangan energi kronik (KEK) pada ibu hamil. Jurnal Kesehatan. 10(3): 220-227.

[2] Andini FR. 2020. Hubungan Faktor Sosio Ekonomi Dan Usia Kehamilan Dengan Kejadian Kekurangan Energi Kronis Pada Ibu Hamil Di Puskesmas Prambontergayang Kabupaten Tuban. Jurnal Armeta Nutritions. 1(1): 218 224.

[3] Ervinawati. Aslis WH, Nurlisis. 2018. Determinan Kekurangan Energi Kronis (KEK) Ibu Hamil Di Puskesmas Lubuk Muda. Jurnal Kesehatan Komunitas. 4(3): 120-125.

[4] Indriany, Siti H, Bunga AP. 2014. Tingkat Sosial Ekonomi Tidak Berhubungan Dengan Kurang Energi Kronis (KEK) Pada Ibu Hamil. Jurnal Gizi dan Dietetik Indonesia. 2(3): 116-125.

[5] Mahirawati. 2014. Faktor-Faktor Yang Berhubungan Dengan Kekurangan Energi Kronis (Kek) Pada Ibu Hamil Di Kecamatan Kamoning Dan Tambelangan, Kabupaten Sampang, Jawa Timur (2014). Jurnal Buletin Penelitian Sistem Kesehatan. 17( 2): 193-202.

[6] Najwa dkk. 2020. Energy Deficiency In Pregnant Women In The Working Area Of Sungai Jingah Public Health Center Banjarmasin 2019. Indian Journal of Public Health Research \& Development. 11(6): 1284-1289.

[7] Pastuty R, Rochman KM, Teti H. 2018. Efektifitas program pemberian makanan tambahan - pemulihan pada ibu hamil kurang energi kronik di Kota Palembang. Jurnal ilmu kesehatan masyarakat. 9(3): 179-188.

[8] Riset Kesehatan Dasar Nasional Indonesia. 2018. Kementerian Kesehatan Republik Indonesia.

[9] Supariasa I, Bakri B, dan Fajar I. 2002. Penilaian status gizi. Jakarta: Penerbit Buku Kedokteran EGC

[10] Triatmaja N.T, Oktovina R.I, Ahmad H. 2018. Determinan masalah gizi kurang (status kurang energi kronis) pada ibu menyusui berdasarkan aspek individu dari rumah tangga di Kota Kediri. Jurnal Wiyata. 5(2): 69-76.

[11] UNICEF. Preventing Iron Defisiency in Women and Children : Background and Consensus on Key Technical Issues and Resource for Advocacy, Planning and Implementing National Programs. Canada : International Nutrition Foundation (INF). 1998

\section{AUTHORS}

First Author - Ida Sumiati, Student of the Master of Public Health Science Study Program

Second Author - Nia Kania, Lecturer in the Master of Public

Health Science Study Program, Faculty of Medicine, Lambung Mangkurat University

Third Author - Syamsul Arifin, Lecturer in the Master of Public Health Science Study Program, Faculty of Medicine, Lambung Mangkurat University

Fifth Author - Meitria Syahadatina Noor, Lecturer in the Master of Public Health Science Study Program, Faculty of Medicine, Lambung Mangkurat University

Sixth Author - Husaini, Lecturer in the Master of Public Health Science Study Program, Faculty of Medicine, Lambung Mangkurat University 
International Journal of Scientific and Research Publications, Volume 11, Issue 1, January 2021

ISSN 2250-3153

www.ijsrp.org 